\title{
CORELATION OF FAMILY ECONOMIC STATUS WITH STUNTING IN THE WORKING AREA OF PUSKESMAS SAMBAU, KOTA BATAM
}

\author{
Siti Iqbalwanty ${ }^{1}$, Meirina Daulay ${ }^{2}$ \\ siti.iqbalwanty@univbatam.ac ${ }^{1}$, meirinadaulay@univbatam.ac.id ${ }^{2}$ \\ 1Professional Doctor Study Program, Faculty of Medicine, Batam University ${ }^{1}$ \\ 2 Medical Education Study Program, Faculty of Medicine, University of Batam ${ }^{2}$ \\ Jl. Abulyatama No 5 - Kota Batam
}

\begin{abstract}
Background : Stunting is a chronic nutritional problem that arises as a result of prolonged malnutrition. The incidence of stunting arises as a result of long-standing conditions such as poverty, improper parenting behavior, and frequent illnesses due to poor hygiene and sanitation. According to WHO, the prevalence of stunting in Indonesia is around 8.9 million, in Riau Islands as many as 262 cases, in Batam City as many as 154 cases. The purpose of this study was to determine the relationship between economic status and the incidence of stunting.
\end{abstract}

Method : The research method used was an analytic survey with a cross sectional approach. Conducted at Posyandu in the working area of Puskesmas Sambau, Batam City, the study was conducted for 6 months, the population in this study were all mothers who had toddlers aged 24-59 months, with a sample of 58 respondents, using purposive sampling technique. Data collection using a questionnaire. Data presented in tabular and textual form, data analysis using Chi-square.

Result : The results obtained were low economic status (55.6\%), and the incidence of stunting (39.7\%). The results of the statistical test of economic status obtained a p-value of 0.004 , so Ho is rejected.

Conclusion :. There is a relationship between Parents' Knowledge of Toddler Nutrition and Family Economic Status with the Incidence of Stunting in Toddlers at the Posyandu in the working area of Puskesmas Sambau, Batam City. It is hoped that parents will pay more attention to the nutrition of children under five so that the incidence of stunting can be reduced

Keywords: Family Economic Status, Stunting

\section{PRELIMINARY}

Stunting is a low growth and cumulative effect of insufficient intake of energy, macro nutrients and micronutrients in the long term, or the result of chronic infection / infection that occurs repeatedly (Umeta et al., 2003). conditions that last a long time such as poverty, improper parenting behavior, and often suffer from repeated illnesses due to poor hygiene and sanitation. Editing in children under five is one indicator of chronic nutritional status that can provide an overview of the disruption of the overall socioeconomic condition in the future. past and in the early 2 years of a child's life can have an impact that is difficult to repair (Sudiman, 2008)

stunting is a condition of short and very short toddlers that exceeds the -2SD deficit. It is a chronic malnutrition problem caused by insufficient nutritional intake for a long time due to feeding that is not in accordance with nutritional needs. Stunting occurs when the fetus is still in the womb and only appears when the child is two years old (MCA-Indonesia and TNP2K, 2017)

Stunting is used as an indicator of chronic malnutrition which describes a child's history of undernutrition in the long term so that stunting shows how the previous nutritional state was (Kartikawati, 2011). Children who are stunted can have an impact on their productivity in adulthood. Research shows that the ability to read in children who are short is lower than in normal children (Gibney, 2009). Many factors affect the nutritional status of children, both direct and indirect factors, as well as the root of the problem. The root of the problem is the economic status which has a negative impact on 
the nutritional status of children (Sembadan Bloem, 2001). The nutritional status of TB / Um provides an indication of chronic nutritional problems as a result of poverty, insufficient feeding patterns, healthy living habits from birth to the result that the child becomes short. Family characteristics, namely family income are associated with the incidence of stunting in children aged 6-12 months (Astari, et al., 2005).

Globally, about 1 in 4 children under five are stunted (UNICEF, 2013). Research conducted by WHO, UNICEF and The World Bank (2012) reported that globally the number of stunted children under the age of 5 was 165 million children or $26 \%$. Asia is the second region after Africa which has the highest prevalence of stunted children, namely $26.8 \%$ or 95.8 million children. Meanwhile, the prevalence of stunting in Southeast Asia is $27.8 \%$ or 14.8 million children. Based on data from Basic Health Research in 2010, the prevalence of stunting among children under five in Indonesia is still very high, namely $35.6 \%$ and in 2013 the prevalence of stunting increased to $37.2 \%$ and the highest prevalence of stunting was at the age of 24-35 months for both men and women. When compared with the "non public health problem" limit according to WHO for a short problem of $20 \%$, all provinces in Indonesia are still in a state of health problems (Ministry of Health, 2010). The prevalence of stunting is higher than the prevalence rate of underweight (19.6\%), 12.1\% underweight and $11.9 \%$ obese (RISKESDAS, 2013).

Stunting is caused by multidimensional factors and not only due to malnutrition experienced by pregnant women and children under five. Some of the factors that cause stunting are poor parenting practices, including a lack of knowledge of mothers about health and nutrition, limited health services including quality Antenatal Care, Post Natal Care and early learning services, lack of household / family access to nutritious food. one of the causes is the economic status of the family, and the lack of access to clean water and sanitation (TNP2K, 2017).

The economic status of the family will affect the ability to fulfill family nutrition and the ability to get health services. Children in families with low economic levels are more at risk of stunting because of their low ability to fulfill nutrition, increasing the risk of malnutrition. Food availability is the family's ability to meet sufficient food needs in terms of quantity and quality and safety. Lack of food availability in a family continuously will cause disease due to malnutrition in the family (Fernald and Neufeld, 2007 in Fikrina and Rokhanawati 2017).

Toddlers aged 24-59 months are included in the nutritionally vulnerable group (the group of people most prone to malnutrition), while currently they are experiencing a relatively rapid growth process. Linear growth disorders, or stunting, occur mainly in the first 2 to 3 years of life and are a reflection of the interaction effect between lack of energy intake and nutritional intake and infection (Fitri, 2012: 3). In line with the research conducted by Ramli et al. (2009) in North Maluku, the prevalence of stunting and severe stunting is higher in children aged 24-59 months, namely $50 \%$ and $24 \%$, compared to children aged 0-23 months. Children 24-59 months of age are at greater risk of stunted growth. The high prevalence of stunting in children aged 24-59 months indicates that stunting is unlikely to be reversible (Anisa, 2012: 2)

The results of 2017 Nutrition Status Monitoring of cases of malnutrition in Riau Islands in 2017 were 262 children under five, spread over 7 districts / cities, the most in Batam (154 children) and the least number in Anambas district (3 children under five) (Riau Islands Provincial Health Office 2018). The city of Batam shows the highest prevalence of stunting in 2017 by sub-district is Bulang $(8.7 \%)$ of the total 106 children under five, Rear Padang $(7.45 \%)$ of the total of 176 children under five, and Nongsa (5.33\%) of the total 424 toddlers (Batam City Health Office, 2017).

From data from the Batam City Health Office in 2017, Nongsa sub-district had the highest prevalence of stunting, namely $5.33 \%$, based on the number of children under five, which was 424 children under five. The data obtained by researchers at the Sambau Nongsa Health Center

Based on the description above, the researcher is interested in conducting a study on the socio-economic relationship with the incidence of stunting in children aged 24-59 months at the Posyandu in the Sambau Community Health Center Work Area. 


\section{RESEARCH PURPOSES}

This research was conducted unituk to determine the relationship between economic status and the incidence of stunting in toddlers 24 - 59 months in Posyandu in the working area of Puskesmas Sambau.

\section{RESEARCH METHODS}

The research method used was an analytic survey with a cross sectional approach. Conducted at Posyandu in the working area of Puskesmas Sambau, Batam City, the study was conducted for 6 months, the population in this study were all mothers who had toddlers aged 24-59 months, with a sample of 58 respondents, using purposive sampling technique. Data collection using a questionnaire. Data presented in tabular and textual form, data analysis using Chi-square

\section{RESEARCH RESULT}

1. Economic Status

The frequency distribution of respondents based on family economic status can be seen in table 1

Table 1

Respondents Frequency Distribution Based on Family Economic Status

\begin{tabular}{cccc}
\hline No & $\begin{array}{c}\text { Family } \\
\text { Economic } \\
\text { Status }\end{array}$ & Frequency & Persen (\%) \\
\hline 1 & Less & 36 & 62,1 \\
2 & Good & 22 & 37,9 \\
\hline & TOTAL & $\mathbf{5 8}$ & $\mathbf{1 0 0}$ \\
\hline
\end{tabular}

From table 1 it can be seen from 58 respondents, it can be seen that as many as 36 respondents $(62.1 \%)$ have a low economic status, and 22 respondents (37.9\%) have a good economic status.

\section{Stunting incidents}

The frequency distribution of respondents based on the incidence of stunting in children under five can be seen in table 2

Table 2

Respondents Frequency Distribution Based on Stunting Incidence

\begin{tabular}{cccc}
\hline No & Stunting & Frequncy & $\mathbf{( \% )}$ \\
\hline 1 & Stunting & 23 & 39,7 \\
2 & Not Stunting & 35 & 60,3 \\
\hline & TOTAL & $\mathbf{5 8}$ & $\mathbf{1 0 0}$ \\
\hline
\end{tabular}

From table 2 it can be seen from 58 respondents, it can be seen that as many as 23 respondents $(39.7 \%)$ stunting in toodler, and 35 respondents $(60.3 \%)$ not stunting toddler.

3. The relationship between family economic status and the incidence of stunting The frequency distribution of respondents based on the relationship between economic status and the incidence of stunting in children under five can be seen in table 3

Table 3

Relationship between Family Economic Status and Stunting

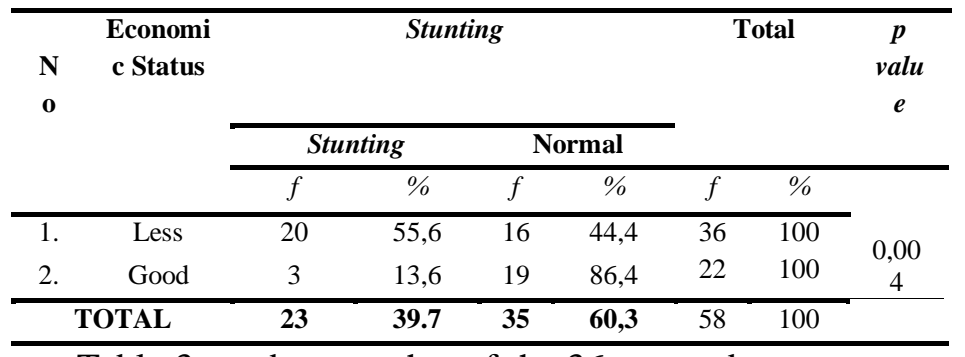

Table 3 can be seen that of the 36 respondents who have economic status, more or less, there are 20 respondents $(55.6 \%)$ who stunting, while 16 respondents $(44.4 \%)$ were normal, and 22 respondents. 19 respondents $(86.4 \%)$ had a normal economic status, while 3 respondents (13.6\%) stunting.

The results of statistical tests using the ChiSquare test with a significance limit $(\alpha)=0.05$, the results obtained p-value $=0.004$ which means p-value $<(\alpha)$, it is said that the two variables have a relationship or Ho is rejected, this means that there is the relationship between economic status and the incidence of stunting in toodler

\section{DISCUSSION}

The results of the research of 58 respondents, it can be seen that as many as 36 respondents $(62.1 \%)$ have less economic status, and 22 respondents $(37.9 \%)$ have good economic status.

This is in accordance with Sulistyoningsih's opinion that an increase in income will increase the opportunity to buy food with better quality and quantity, on the other hand a decrease in income will cause a decrease in the purchasing power of food both in quality and quantity. High income which is not balanced with 
sufficient nutritional knowledge, will cause a person to become very consumptive in his daily diet, so that the selection of a food ingredient is based more on taste considerations than nutritional aspects. A non-stunting condition occurs when the body gets enough nutrients. used efficiently, thereby enabling physical growth, brain growth, employability and general health at the highest possible rate. Undernutrition status occurs when the body is deficient in one or more essential substances.

Based on the research analysis, the economic status of the family is still inadequate or it can be said that it is still under the category $\leq$ UMK (minimum wage for work) and also occupational factors such as laborers and housewives. So that indirectly to meet daily nutritional needs will also have an effect. The economic status of the family that is still lacking can affect the nutritional condition of the family, especially the needs of children under five in their infancy.

Families with insufficient socioeconomic conditions with a large number of children will result in unfulfilled primary needs such as food, clothing and housing (Soetjiningsih, 1995). The results of Nasikhah's (2012) study indicate that the level of per capita income shown in expenditures for expenditure is a risk factor for stunting in Balitadi in East Semarang with an OR of 7.21. Similar research also states that low family food expenditure has a 6.353 times greater risk of experiencing stunting than families with high expenditure (Annisa, 2012).

According to Arifin (2004), the greater the food expenditure in the household, the lower the household food security, this is related to the ability to access food. According to Berg (2010), increasing expenditure on consumption is not always followed by improvements in food consumption patterns. Even though a person tends to spend most of his income on consumption, it is not certain that what he eats is good in quality. In addition, the ability of a family to buy food is not only affected by the amount of income but the price of foodstuffs. Some of the prices of expensive food ingredients tend not to be selected and purchased, so in the family this type of food is rarely served so that in meeting nutritional needs it is still lacking.

The results of the research of 58 respondents, it can be seen that as many as 23 respondents $(39.7 \%)$ experienced stunting in under-five, and 35 respondents (60.3\%) did not experience stunting. Stunting is caused by multi-dimensional factors and not only caused by factors. malnutrition experienced by pregnant women and children under five. Some of the factors that cause stunting are poor parenting practices, including a lack of knowledge of mothers about health and nutrition, limited health services including quality Antenatal Care, Post Natal Care and early learning services, lack of household / family access to nutritious food. one of the causes is the economic status of the family, and the lack of access to clean water and sanitation (TNP2K, 2017)

Previous research has been conducted by Fikrina (2017) who conducted research on the relationship between socio-economic levels and the incidence of stunting in children aged 24-59 months in Karangrejek Village Wonosari Gunung Kidul. The research variables used were the incidence of stunting, family income, maternal education, and maternal occupation. The results showed that the proportion of the sample who experienced stunting was 47 underfive and the nutritional status of normal TB / U was 74 under-five. There were 23 stunting toddlers with low family income and 24 underfives $(\mathrm{p}$-value $=0,000), 61$ people with low education and 60 higher education ( $\mathrm{p}$-value $=$ 0.019 ), and 92 non-working mothers and mothers. who worked 29 people ( $\mathrm{p}$-value $=$ $0.154)$. There is a significant relationship between family income and maternal education with the incidence of stunting among children under five.

The results of this study are consistent with research conducted by Candra (2011) in Semarang which states that low income levels are a risk factor for the incidence of stunting, where families with low incomes have a 2.3 times greater risk of having stunting children than families with sufficient income. The results of research in North Maluku (Ramli, et al., 2009), and in Nepal (Taguri, et al., 2004) state the same results that low income is associated with the incidence of stunting in children under five. According to Adriani (2012), family purchasing power for nutritious food is influenced by family income because determining the type of food to be purchased depends on the level of income. The purchasing power of household food follows the level of family income. With high income, it is possible to fulfill the food needs of all family members. 
However, on the other hand, the low level of family income results in low household diversity. The low purchasing power of foodstuffs causes insufficient fulfillment of nutritional needs (Ranoor, 2010).

This result is in line with the research of Candra (2013), in Semarang and Ramli et al. (2009), in North Maluku which stated that low income is a risk factor for the incidence of stunting in children under five. Low economic status is considered to have a significant impact on the likelihood of children becoming thin and short (UNICEF, 2013). According to Bishwakarma (2011), families with good economic status will be able to get better public services such as education, health services, road access, and others so that they can affect the nutritional status

of children. In addition, the purchasing power of families will increase so that family access to food will be better

\section{CONCLUSION}

Based on the results of research conducted on 58 mothers who have children under five, the following results were obtained:

a. As many as 36 respondents $(62.1 \%)$ had low economic status.

b. As many as 35 respondents $(60.3 \%)$ did not experience stunting in their toddlers.

c. There is a relationship between the economic status of the family and the incidence of stunting in children under five, $p$ value $=0.004$

\section{SUGGESTION}

\section{For Respondents}

It is hoped that it can increase knowledge and information both from printed media, electronic media, health workers and others about the incidence of stunting in children under five, so that in the future respondents can take care as early as possible so that the same incident does not occur again.

2. For Research Sites

It can be used as additional information for cadres in posyandu in collecting data on stunting in toddlers, and it is advisable to always collaborate with the puskesmas in counseling about providing proper nutrition for toddlers so that parents are expected to meet their children's needs.

3. For Further Researchers

It is hoped that further researchers can further investigate stunting by including other variables that have not been examined in this study, such as parental education, age, and low birth weight because researchers find one other factor that causes stunting.

\section{DAFTAR PUSTAKA}

Agustiningrum. 2016. Hubungan Karakteristik Ibu Dengan Kejadian Stunting Pada Balita Usia 24-59 Bulan di Wilayah Kerja Puskemas Wonosari I

Anjani, A. D. (2018). FAKTOR FAKTOR YANG BERHUBUNGAN DENGAN IBU YANG MEMBAWA BALITA TIMBANG KE POSYANDU. Jurnal Kebidanan Malahayati, 4(2).

Ariani A, P, (2014). Aplikasi Metodologi Penelitian Kebidanan Dan Kesehatan Reproduksi, Nuha Medika, Yogyakarta

Aridiyah, dkk. 2015. Faktor-Faktor Yang Mempengaruhi Kejadian Stunting Pada Anak Balita di Wilayah Pedesaan Dan Perkotaan.

Aulia, Devy lestari Nurul (2018). Pengaruh Pemberian Promosi Kesehatan Terhadap Pengetahuan Ibu Tentang Perkembangan Motorik Halus Pada Anak Prasekolah Usia 3-5. Jurnal Kebidanan Malahayati 4(1)

Atikah dan Siti. 2009. Ilmu Gizi Untuk Keperawatan dan Gizi Kesehatan.

Bhutta, Z. A dan Khanjilal. 2010. Kekurangan Gizi Ibu Dan Anak

Budiman \& Riyanto. 2013. Kapita Selekta Kuesioner Pengetahuan Dan Sikap. Dalam Penelitian Kesehatan. Jakarta : Salemba Medika

Dainty Maternity, S. S. T., Keb, M., \& Anjani, A. D. (2018). ASUHAN KEBIDANAN NEONATUS, BAYI, BALITA, DAN ANAK PRASEKOLAH. Penerbit Andi

Dinas Kesehatan. 2017. Laporan Angka Stunting Berdasarkan Angka WHO2005. Batam

Dinas Kesehatan Provinsi Kepualau Riau. 2018. Hasil Pemantauan Status Gizi tahun 2017. Kepulauan Riau

Disnaker Provinsi Kepulauan Riau. 2017. Perubahan UMK di Kepri

Doriza. 2015. Ekonomi Keluarga. Jakarta

Dr. Marudut. 2017. Kebutuhan Gizi Anak Lakilaki da Perempuan Berbeda. 
Fikrina. 2017. Hubungan Tingkat Sosial Ekonomi Dengan Kejadian Stunting Pada Balita Usia 24-59 Bulan di Desa Karangrejek Wonosari Gunung Kidul.

Fitri. 2012. Faktor Dominan Terjadinya Stunting Pada Balita di Sumatra. Depok : Universitas Indonesia

Gibney, dkk. 2009. Gizi Kesehatan Masyarakat. Jakarta : EGC

IFPRI. 2014. Global Nutrition Report. 2014 Nutrition Country Profile Indonesia

Ibrahim, Faramita. 2014. Hubungan Faktor Sosial Ekonomi Keluarga dengan Kejadian Stunting Anak Usia 24-59 Bulan di Wilayah Kerja Puskesmas Barombong Kota Makassar Tahun 2014. Jurnal Ilmu Kesehatan. Universitas Alauddin Makassar Kementrian Kesehatan RI . 2010. Kategori dan Ambang Batas Status Gizi Anak 2016. Situasi Balita

Pendek. Jakarta Selatan 2017. Buku Saku Pemantauan Status Gizi Tahun 2017

Kusumawati, dkk. 2015. Model Pengendalian Faktor Risiko Stunting Pada Anak Usia di Bawah Tiga Tahun

MCA-Indonesia. 2017. Stunting dan Masa Depan Indonesia

Maternity, Dainty; Ratna, DP; Devy, LNA. (2017). Asuhan Kebidanan KomunitasDisesuaikan dengan Rencana Pembelajaran Kebidanan. Penerbit Andi, Yogyakarta

Marudut, dr. 2017. Perbedaan Gizi Anak

Nazriwati, N., \& Anjani, A. D. (2021). HUBUNGAN PENGETAHUAN DAN SIKAP IBU BAYI (USIA 7-11 BULAN) TENTANG ASI EKSKLUSIF DENGAN PENERAPAN ASI EKSKLUSIF DI PUSKESMAS BALOI PERMAI KOTA BATAM TAHUN 2017. Zona Kebidanan: Program Studi Kebidanan Universitas Batam, 8(2).
Ngaisyah, Dewi. 2015. Hubungan Sosial Ekonomi Dengan Kejadian Stunting Pada Balita di Desa Kanigoro, Saptosari, Gunung Kidul

Ni'mah, Nadhiroh. 2015. Faktor yang berhubungan dengan kejadian stunting pada balita. Media Gizi Indonesia. Fakultas Kesehatan Masyarakat Universitas Airlangga Surabaya.

Notoadmojo, S. 2010. Promosi Kesehatan.

Jakarta : Rineka Cipta

S. 2012. Metodologi Penelitian.

Jakarta : Rineka Cipta

Nurul Aulia, D., \& Anjani, A. (2019). Hubungan Pengetahuan dan Sikap Ibu Balita dengan Perilaku Keluarga Sadar Gizi (KADARZI). Journal for Quality in Women's Health, 2(1), 36-42. Retrieved from

https://www.jqwh.org/index.php/JQWH/a rticle/view/25

Pemantauan Status Gizi. 2017.

Putra. 2015. Pengaruh BBLR Terhadap Kejadian Stunting Pada Anak Usia 12-60 Bulan di Wilayah Kerja Puskesmas Pauh Pada Tahun 2015. Skripsi : Fakultas Kesehatan Masyarakat Universitas Andalas Padang.

Pormes, Rompas, Ismanto. 2014. Hubungan Pengetahuan Orang Tua Tentang Gizi dengan Stunting Pada Anak Usia 4-5 Tahun. Skripsi : Program Studi Ilmu Keperawatan Fakultas Kedokteran Universitas Sam Ratu Langi Manado Puskesmas Jabi. 2017. Profil Puskesmas Jabi Puskesmas Sambau. 2017. Status Gizi Balita

Kecamatan Nongsa. Batam

RISKESDAS. Laporan Hasil Riset Kesehatan Dasar Indonesia Tahun 2010 dan 2013. Jakarta: Departemen Kesehatan RI, 2011 dan 2014.

Rumengan, dkk. 2015. Metode Penelitian

Kualitatif. Medan. Perdan Publishing

SDKI. 2012. Survei Demografi dan Kesehatan Indonesia

Siahaan, dkk. 2013. Faktor-faktor Yang Berhubungan Dengan Kejadian 
ZONA KEDOKTERAN - Vol. 11 No. 1 Januari 2021

Stunting Pada Balita di Wilayah Kerja

Puskesmas Tanjung Tiram

KecamatanTanjung Tiram Kanupaten

Batu Bara Tahun 2013

Sriningsih. 2011. Faktor Demografi,

Pengetahuan Ibu Tentang Air Susu Ibu Dan Pemberian ASI Eksklusif. Jurnal Kesehatan Masyarakat.

Susenas. 2012. Survei Sosial Ekonomi Nasional 